\title{
The importance of networking as a management skill
}

\author{
S. de Klerk \\ School of Business Management, Faculty of Economic and Management Sciences, \\ North-West University, Private Bag X6001, Potchefstroom 2520, Republic of South Africa \\ Saskia.DeKlerk@nwu.ac.za
}

Received October 2009

\begin{abstract}
Networking is a life skill and it is in managers' interest to acknowledge its importance and develop their own networking skills. This article reports on networking practices in Gauteng businesses. The empirical study consisted of an exploratory, sequential mixed-method research design, which included five focus group discussions $(n=41)$ to investigate the content of the networks and a structured questionnaire aimed at analysing the perceptions and experiences of business owners and managers in Gauteng Province in South Africa on the structure of their networks. The participants considered networking important to business success and stated that they would have benefited from training on building relationships, earlier on in their careers. Based on these findings, it is recommended that educators at all levels, managers and policy makers focus on networking as part of management training.
\end{abstract}

*To whom all correspondence should be addressed.

\section{Introduction}

What is a network? A network consists of a set of nodes (for instance, organisations, individual, work unit) and ties (relationship) (Brass, Galaskiewicz, Greve \& Tsai, 2004: 795). Networking can be described as the action different independent nodes with direct and/or indirect links (De Man, 2004: 4) that form an alliance based on mutual interest (Webster third new international dictionary of the English language, 1976:1519-1520) and to develop a strategic competitive advantage (De Man, 2004: 4). The nature of networking is determined by the underlying motivation of the individual to acquire what he or she needs/desires from the other person. Networking has been described as a psychological need to connect, socialise and work with others (Van Winkelen, 2003). Networking relationships offer support and comfort (Boe, 1994: 9) that can increase one's own value and in turn attract other people to your network (Taylor, 2006: 6, 9).

Kay (2004: 166), Taylor (2006: 5) and Boe (1994: 8) mention that certain people appear to be born with the instinct for building and the natural ability to build the appropriate connections and relationships. Others may have to acquire these skills by trial and error and the approach to acquiring these depends largely on the individual's attitude and willingness to move out of his or her comfort zone. Different personality types appear to apply their personality traits, such as temperament, cognition and choice of interaction (Miller, 2003: 419), with unique style and application to business networking (Nierenberg, 2005a: 3).

Ward (2000: 131) mentions that an individual brings his or her own emotions, fears, and perceptions of various social organisations and groups to the networking arena. More examples of different groups or organisations that have developed a general idea of good conduct towards networking are different cultures. For instance, traditional extraverted cultures, like the Americans, rely more on interpersonal networks of information or personal connections (Mooradian \& Swan, 2006: 778-779).

Networking is not restricted to specific situations and people can network at any time and place, which makes every opportunity a networking opportunity (Yeung, 2006: 18). Networking relationships allow for successful business practices and the development of mutual respect (Kay, 2004: 6), trust and social capital, which contribute to the success of networking efforts in a business (Yeung, 2006: 9). Igwebuike (1998) directed the importance of trust and mutual respect in business practice to management by stating that business managers need to engage in some form of networking in order to increase their job satisfaction. In order to benefit fully from networking, managers need to first acknowledge the importance of networking and establish strategic networking relationships (De Klerk \& Kroon, 2008: 89).

In general, it appears that businesspeople are required to know how to network; yet little training or explanation of what networking skills entail is provided (White, 2004: 3). Networking is a valuable skill by which to facilitate cooperation that may lead to overall community building (Lindenfield \& Lindenfield, 2005: 233), which requires continuous practice and patience (Fischer, 2005: 38). It thus makes sense to incorporate networking as a skill of building and sustaining relationships in business and management training, as a life-enriching and quality-of-life skill that managers can use to create opportunities and reap the benefits that it holds for businesses (Lindsay, 2005: 18). Little research has been conducted thus far on the networking practices of South African business owners and 
managers, with most networking literature originating in Europe or America. The South African political and business environments have undergone dramatic changes since 1994 with the end of Apartheid, which resulted in the incorporation of a variety of racial groups, not formerly involved in most formal business practices, and marked the end of sanctions that opened the market for foreign business involvement. The current study contributes to the broader scientific base of networking literature, as very few scientific readings related to the South African context exist.

In this article, individual views on networking amongst business owners and managers in Gauteng were investigated. The investigation included the perceptions of what networking entails; individual experiences of networking practice, in terms of the way individuals network; where individuals begin developing a network; the importance of networking in business; and incorporating networking as a management skill in business and management training programmes.

\section{Research methodology}

\section{Research design}

The exploratory, sequential mixed-method approach used in this study included a combination of qualitative and quantitative methods (in following De Vos, 2005: 361), in order to increase the researcher's understanding (Creswell, 1994) of the phenomenon of networking practices. Figure 1 provides an illustration of the mixed-method approach used in this study.

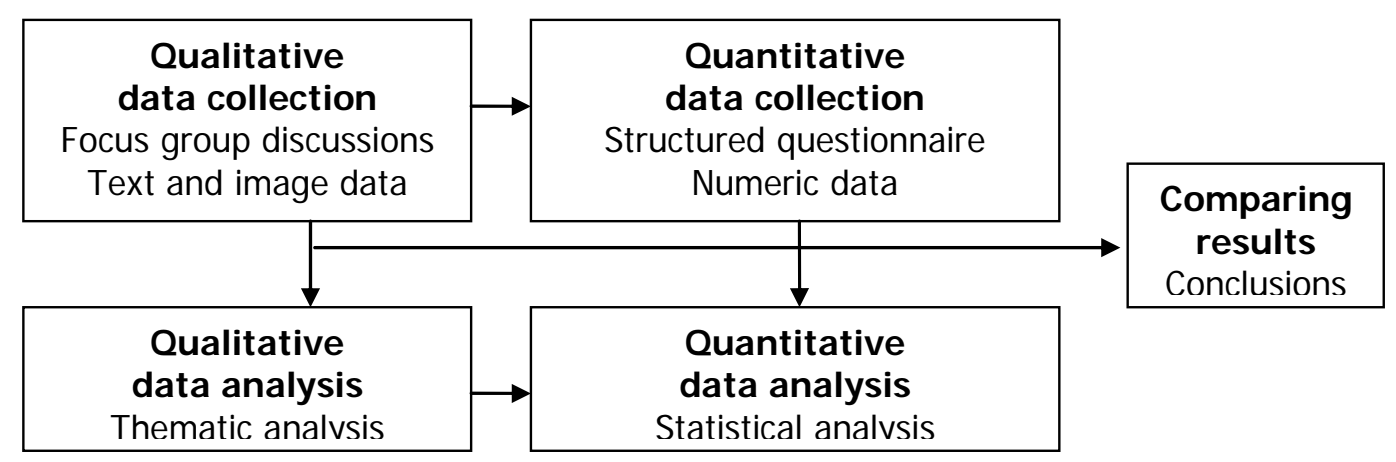

Figure 1: Exploratory, sequential mixed-method design

Both the objectivity of the topic through the ontology and epistemology of the relationship between the role-players and their particular environment, as well as the subjective hermeneutic understanding of the topic can be investigated (Marschan-Piekkari \& Welch, 2004: 163). A combination of these methods may lead to a better understanding and theory generation (see Pearse \& Smith, 2005: 50) of networking amongst business people in South Africa.

\section{Focus group discussions}

\section{Participants and procedure}

A non-probability, purposive, voluntary sample was used in this study. A networking expert was selected in a purposive sample to be the host of the focus group discussions. The criteria for inclusion were that the participants had to be: English- or Afrikaans-speaking; Gauteng business owners or managers; willing to participate in the focus groups and to share their knowledge of networking; and willing to be contacted afterwards for cross-member checking. The participants of the remaining four focus group discussions were selected by making use of a snowball sample of referral networks, including friends, colleagues and business acquaintances. Referrals are a networking technique and were used to gain access to interweave networking connections.

In order to ensure that at least eight participants would be available for each focus group, fifteen to twenty potential participants were invited. This resulted in groups of between eight and twelve participants (this excludes the host). Saturation was reached after three focus group discussions. A further two focus group discussions were conducted in order to include additional female participants and participants of various racial classifications, as well as to corroborate the findings from the first three focus group discussions and add to the richness of the direct quotations data already gathered. Therefore, five focus group discussions were held with a total of 41 participants. The details regarding the number of participants according to their sex, as well as the field or industry in which they work are summarised in Table 1. 
Table 1: Profile of the focus group participants

\begin{tabular}{lll}
\hline Group & Participation according to sex $(\mathbf{n = 4 1 )}$ & Field or industry in which the participants are involved \\
\hline 1 & 8 men & $\begin{array}{l}\text { Financial, Insurance, Real estate and Business services } \\
\text { Participants from various industries, such as engineering, banking and marketing } \\
\text { institutions. } \\
\text { Participants from various companies in the IT and R \& D fields } \\
\text { Participants from engineering, exports, patent law, Financial management and } \\
\text { innovation backgrounds. } \\
\text { Participants from marketing, IT, communication, investment and trading } \\
\text { backgrounds. }\end{array}$ \\
\hline
\end{tabular}

\section{Data collection}

Focus group discussions are explorative in nature and were used as a technique by which to induce value-exchange opportunities for the participants. The participants all have time constraints and therefore something of value had to be offered to encourage their participation in the discussions; this was provided in the form of an influential person (person of stature amongst the business community). The participants travelled to a central, familiar venue in order to reduce time spent on travelling. Traffic was also a consideration and therefore a breakfast session, starting at 7:00 am, was scheduled. The discussions were limited to between 1.5 and 2.5 hours.

The venues were boardroom facilities or privately booked coffee shops at which a 'do not disturb' sign was placed outside the door to ensure no interruptions. Initially, the host introduced and explained the objectives of the focus group discussion, and then the participants introduced themselves and signed consent forms to participate in the research project and to be recorded. Participants were informed of the confidentiality and anonymity of the information outside the focus group context and assured that they could withdraw from the research project at any time.

The focus group agenda included the following questions for all the groups: What are your ideas or perceptions regarding networking practices?; What is the role of trust in networking?; What do you perceive as the most important similarities and/or differences in terms of the role of trust in external and internal networking practices?; Identify some success factors crucial to establishing trust; and Identify some crucial obstacles or deterrents in the establishment of trust.

The researcher took field notes (information on particular behaviour or specific occurrences; according to Breakwell, 2004), contextual notes (comments on the venue, setting and other important aspects), personal notes (personal reflections on her own experiences and observations of the session and environment), and observational notes (a summary of any positive or negative influences or situational happenings that might have an influence on the discussions; following Holloway and Wheeler, 2002). Impressions were written down directly after each focus group discussion, in order to assist the researcher's recall of the discussion and to reduce the risk of loss of data.

The researcher made use of the following techniques during the interviews: paraphrasing (noting cases of expressions restated in other words), minimal responses (recording of what is implied through body language and verbal responses, such as $u h-h m$, yes, I see), clarification (the researcher sought clarification of unclear statements), reflection (was used by the researcher to encourage the participants to provide more detail on something said), and summarising (stating something in a concise manner to ensure that interpretation was correct), all of which enabled the researcher to know when to move on to another idea or to review the meaning of the words.

\section{Data analysis}

Focus group discussions were video- and audiotaped for verbatim transcription by an independent transcriber. Creswell's (1994) theme approach was followed in this study, which included seven steps of data analysis:

1) The transcript data was checked several times and from different perspectives, and the transcripts were formed in three columns, reflecting the researcher's thoughts and experiences (column 1), the text (column 2) and the themes (column 3; in following Creswell, 1994; Daymon \& Holloway, 2002; Greeff, 2006).

2) As themes emerged, data was grouped using the NVivo 2.0 software program (QSR, 2002a \& 2000b; Richards, 2002);

3) Then the data were grouped into main, sub- and additional themes to seek underlying relationships (in following Daymon \& Holloway, 2002).

4) Thereafter, the large amount of data grouped into fragmented sub-themes was grouped into more coherent and focused main themes. Relationships were also investigated between the different sub- and the additional themes (in following Daymon \& Holloway, 2002).

5) Concrete language of the participants had to be converted into scientific language, supported by direct 
quotations. Based on insights gained, integration and synthesis of the identified themes were then done.

6) After this, member-checking was conducted to ensure the trustworthiness of the content analysis. This entailed sending sections of the report of the results to various participants.

7) The process of ensuring trustworthiness was continued by making use of a co-coder, in order to ensure that the identified themes and sub-themes corresponded. In cases of any differences, a third (independent) person was contacted to provide an objective perspective.

\section{Trustworthiness}

Guba's model for qualitative research (Guba, 1981; Krefting, 1991; Lincoln \& Guba, 1985) was applied in order to ensure the trustworthiness of the findings. In accordance with this model, the transcripts were converted into scientific language and presented for validation through member-checking. Member-checking involves sending selected participants selected extracts from the report of the findings and requesting that they confirm or clarify specific aspects of the findings (Daymon \& Holloway, 2002: 232). The truth value of the findings was ensured by taking field notes, independent transcription, ensuring the transferability/applicability of the data, describing the data in full, consistency of the findings, retaining all raw material, describing the research methodology in full, keeping an audit of the process, applying the same procedure throughout, using peer examination and conformability (one process throughout for all the focus groups), as well as the using triangulation and the code-recode procedure.

\section{Ethical aspects}

Only the researcher, peer reviewers and transcribers were allowed access to the audio and video recordings, in order to ensure confidentiality and respect the participants' right to privacy. Names or specific information on the discussions were not disclosed to anyone outside of the study. The participants gave consent by signing a consent form and participated voluntarily. Contact details for further information were supplied. The researcher acted in an honest, fair and respectful way towards the participants and did not attempt to mislead of deceive them at any time, in order to retain an ethical climate (in accordance with Kruger, De Vos, Fouché \& Venter, 2005: 217).

\section{Questionnaire}

\section{Respondents and procedure}

An e-mail regarding the questionnaire and additional information on the project was sent to the focus group participants and the chairpersons of the Afrikaanse
Handelsinstituut (AHI) chambers of commerce in the Gauteng region. The questionnaire was accessible via a hyperlink to a web site. Thirty-five participants responded to the survey. The e-mail sent to each respondent contained a short introduction to the nature of the research and the value of the contribution, the instructions, deadline, and information on issues surrounding confidentiality and anonymity (in following Cooper \& Schindler, 2003: 123). The questionnaire was sent on three different occasions during the Easter holiday season. Table 2 provides a profile of the respondents who ranged in age from younger than 23 to 60 , with an average age of 50 years.

Table 2: Biographic information on the questionnaire respondents

\begin{tabular}{llc}
\hline Item & Category & Total (\%) \\
\hline Sex & Male & 82,86 \\
& Female & 17,14 \\
Age & $<25$ & 5,71 \\
& $25-34$ & 8,57 \\
& $35-44$ & 20,00 \\
& $45-54$ & 45,71 \\
Race & $>55$ & 20,00 \\
& White & 94,29 \\
Education & Black & 5,71 \\
& Grade 12 & 9,38 \\
& Diploma/certificate & 6,25 \\
& Bachelor's degree & 28,13 \\
& Postgraduate degree & 56,25 \\
\hline
\end{tabular}

The findings show that the largest percentage of participants and therefore business owners and managers are white males which correlate strongly with other research which reported that $61 \%$ of top management are white males (South Africa Info, 2009).

Participants had to classify their businesses according to three business sectors, namely services, retail or trading businesses and the manufacturing sector. The highest percentage of participants (79.41\%) was involved in the services industry while the second highest percentage (11.76\%) was involved in the manufacturing business sector.

\section{Measuring instrument(s)}

The e-mail questionnaire consisted of seven sections requiring: 1) nominal data on respondents' biographical details; 2) respondents' networking practices and their view of networking; 3) respondents' reasons for networking and the aspects of their networking efforts; 4) the extent to which businesses currently network and the ideal situation for networking in respondents' specific circumstances; 5) rating answers on a scale of one to four in order of importance or according to the frequency of networking business activity experienced; 6) rating answers by selecting one of four options: strongly agree, agree, disagree or strongly disagree with the statements; and 7) providing open responses in order to share their own experiences, additional comments or concerns. 
In the fourth section, cross-tabulations were used to compare results and display joint-frequencies for two variables (Kruger et al., 2005: 239). The two variables in these questions included the current and ideal business or personal practices of networking. The significance of this data was measured using the chi-square test.

\section{Data analysis}

The questionnaire data was analysed by making use of SAS statistical program (SAS Institute Inc, 2005a \& 20005b). Inferential statistics (in other words $p$-values) were inappropriate for this study, because of the small sample size and sampling method. The effect sizes of Cohen $(d-$ values; Cohen, 1988:223), which indicate the differences between answers, were used. The practical significance of the relationship between current and ideal business or personal practices of networking was analysed by using the Cohen formula for calculating effect sizes. In this, the population standard deviations $\sigma_{1}$ and $\sigma_{2}$ are not equal, but $S_{\max }=$ maximum of $S_{1}$ and $S_{2}$ was taken as the sample standard deviations (Ellis \& Steyn, 2003: 52):

$$
\mathrm{d}=\frac{\left|\overline{\mathrm{x}}_{1}-\overline{\mathrm{x}}_{2}\right|}{\mathrm{S}_{\max }}
$$

A large effect size $(d=>0.8)$ indicates a practical significance, a medium effect size $(d=0.5)$ indicates a substantial finding, and a small effect size $(d=0.2)$ indicates no difference. Relative frequency distribution, whereby the data is reported in terms of relative proportion to the total number of responses, was calculated.

\section{Results}

The findings of this study were arranged into perceptions and experiences as they were expressed by the participants. These findings were divided into different main, sub- and additional themes by making use of open coding through the theme approach. For the purposes of discussing the individual's influence on networking, the following three perceptions were included: networking as a conscious or unconscious activity, networking as an emotional connection and each network has a character of its own. The experiences of the participants that emerged as main themes of human or individual networking included: networking occurs naturally, networking is a technique and when to start to develop networking. Networking is a technique had a sub-theme networking as part of management. When to start to develop networking included sub-themes networking in families, networking at nursery school level, networking at school, networking at university, networking at work, networking at cultural and community events, networking at networking events and networking in the chamber of commerce.

\section{Perceptions of networking as a conscious or unconscious activity}

Participants mentioned that networking appears to be the result of the human need or inclination to seek company and to socialise with others. Networking with others, being in the company of others and building relationships with other people are basic needs for humans. The following statements by focus group participants are given here to enrich this finding: "The concept of networking as an informal, everyone-does-it, almost as a human need that you find in all relations and on all levels, that is the relationships that we build on". The human inclination to network is supported in the literature by Koniordos (2005) and Kadushin (2002), who describe networking as a human need or natural occurrence, for which people's need to socialise, belong and be part of something more than they can build on their own is the main motivation behind the tendency to approach other people.

Participants indicated that they feel that people decide to start to network at a conscious or unconscious level. Some of the participants were not able to explain their decision to attend the focus groups, while others had a specific reason in mind. The following verbal quotations demonstrate this idea: "Networking is not always a conscious decision it sometimes happen, 70\% of the time, subconsciously. You do network; you network all the time. You may not do it consciously." In some instances, the form of networking may influence the decision to either consciously network; in others, networking may occur unconsciously, for example: "It might be unconscious networking within your organisation and your external network may be consciously. Within your internal network, within your organisation it consists of people sharing resources. Your external network is where you decide who is going up and who is going out or just to open doors."

Participants (40\%) perceived networking as a skill and no participants perceived it as a natural phenomenon only. However, $60 \%$ of participants indicated that they perceive networking as the result of both. This result is also indicative of the findings in the focus group discussions that networking is as much a skill that can be taught and enhanced as it is the natural ability to communicate and build relationships.

\section{Perceptions of networking as an emotional connection}

It appears that participants perceived networking as being adaptable to various situations and seems to be developed from an emotional connection or personal decision to network; it is developed at an emotional level at which the individual feels the need for emotional support or sharing. The following quotations illustrate this finding: "But in the end $90 \%$ of the network is built on an emotional relationship and trust where you trust that the guy is really going to walk the path with you." and "There is an emotional connection in networking." 
According to Lewis (2003: 134), an individual can decide whether to participate in a network based on circumstantial, emotional or the lack of any connection. This is supported by Van Winkelen (2003), who states that being a member of a community or an organisation entails both an intellectual and an emotional component.

\section{Perceptions of each network having a character of its own}

Participants indicated that each network has a character of its own and needs to include the appropriate combination of people with ability and trust, which poses a major challenge to all networkers and is crucial to the success of a network. The following quotation supports this finding: "It's the combination of people you know and by proving your ability to deliver the important things are a mutual beneficial relationship. Personal satisfaction or gratification, is where I do something for him, I will get something in return, as opposed to when you meet somebody through a mutual friend. The barriers are lowered. You trust others." Frazier and Niehm (2004: 30), amongst others, indicate that the different role-players' expertise and previous successes will influence the quality and frequency of networking activity. Möller, Rajala and Svahn (2005: 1280) state that an individual's or a business' ability as a whole will predetermine and influence the decision to be included or excluded in a specific networking relationship.

\section{Experiences of networking}

Participants indicated that they had experience networking as an important skill. Most business people however lack these skills because networking is perceived as a natural skill for which an individual has a natural affinity and one that cannot be forced. The following quotation illustrates this finding: "I think that most of us here have a personality handicap. We are raised with the idea that when you work you sit at a table and type on your keyboard. When you go around, see people and socialise, it is not work. We appoint people that socialise as a work, because we think the guys working there at the moment cannot." The concept of networking as a skill that needs to be developed was supported by the literature (see for example Zweibel, 2006), where it is described as a key skill to expand the individual's world. Business people wish to be at liberty to create a unique and individual approach to networking (Koniordos, 2005: 60).

\section{Experience of networking as a natural occurrence}

According to the participants, networking is an activity everybody has to engage in, but it should come naturally and cannot be forced. Some people have mastered networking in such a way that they can apply it for specific reasons and in specific ways, others have to work at it. This is either because of their personalities that hamper networking, their limited exposure to it or ignorance towards the advantages thereof. Supportive quotations in this regard include: "But it [networking] is not a natural thing that you are just born with." and "I would say an important point is that I think some guys network naturally. For some it does not come naturally." The literature supports this finding. For example, Wainwright (2004: 28) states that relationships are built naturally through a mutual desire to be part of the network. Impact Factory (2006) states that business people can be taught to use networking skills with ease and confidence, and Takash (2004: 24) states that these skills need to be acknowledged in business and further developmental steps or training should be provided.

\section{Experiences of networking as a technique}

The overall feeling amongst participants was that there is a gap between being able to network naturally and the available resources, courses or opportunities to develop the necessary skills. Networking is regarded as consisting of various techniques and applications that are developed through training and personal practice. This perception is indicative of the need for further skills development in the form of relevant courses or workshops in order to assist individuals to develop these skills. The following are supportive quotations: "Most people in South Africa aren't born with the ability to network. It is not easy for anybody to just go out to somebody and start speaking to him. It is a skill you need to be taught." It thus seems that most of the participants feel that networking is a skill that is yet to be taught: "You must still be taught how to network. Some will be better than others." and "I think you can be taught how to build a network in terms of certain techniques and certain things. Sometimes you will say well you know that does not work, and a person just out of school, that's an amateur." The literature confirms this finding with Nierenberg (2005b: viii) that mentions that networking can be described as an art and skill that enables an individual to make beneficial contacts and expand his or her business and personal opportunities. Taylor (2006: 7) also supports the notion of networking as a skill that can increase an individual's own value to others.

\section{Experiences of networking as part of management}

The participants mentioned that management needs to implement successful networking practices and enhance their networking efforts. This can be achieved by acknowledging the value of networking and giving special attention to the enhancement of management's ability to network: "Networking plays a role in company success but it isn't company success." and "People in the company view the company resources in the wrong way, they think they have capital and assets for projects." Takash (2004: 24), amongst others, discusses the direct effect of successful networking on the success of business management and stresses the importance of acquiring suitable skills to be able to manage the networking process successfully. 


\section{Experiences of when to start networking}

All participants were of the opinion that networking is a necessary activity, but had different opinions as to an appropriate age to start networking. In general, the participants had experienced that one is never too young to start developing the necessary networking skills and to start building a personal network of contacts and relationships.

\section{Networking in families}

Participants stated that in their experience individuals who are exposed to networking in their family contexts acquire networking skills at an early age. The following quotation supports this finding: "How many people have the patience to build Amway over five years? Now why are successful families successful in Amway? They have a network, they know how to communicate, they know how and they grew up with that network. Grew up with it, you can't come and get it." Butler (2004: 197-198) states that families play an important role in the early development of life skills in an individual's life and in the identification of opportunities, giving referrals and supporting the process of development and conducting the activities. Rothmann and Van der Bank (2006: 30) further mention that family support helps an individual to adjust more easily and to work through emotional or work stress. The finding does, however, also indicate that families need to acknowledge the importance of networking skills in raising their children - an aspect that is not explicitly discussed in the literature.

\section{Networking at nursery school level}

Participants shared their experience that people tend to group together and seek out others with similar characteristics. Starting to acquire and develop networking skills from an early age is regarded as important, and the natural socialisation of children at nursery school level is one locus where this can commence. The following quotation supports this: "In nursery school, from day one, it isn't really forced networking, but getting to know each other. We got used to only help oneself." Literature sources acknowledge the nursery school stage as a place where networks are developed (Thompson, 1996:49; Neal, 2009:737), but it is not emphasised as a place to develop these more natural social connections to use as referral networks or business networks in the future. Therefore, this finding is unique and adds a rich dimension to the current study.

\section{Networking at school}

Participants indicated that they would have liked to have acquired good communication and social skills in a structured manner at an early age at school or at home. The following statements illustrate this finding: "Children aren't taught to network really, at school or anywhere, and it needs to be a priority and it is not given any attention from what I still see even in the new curriculum at school or any of the levels and I think that is a big gap in our learning curriculum as well as our society today. It is not taught to children." Tullier (2004: 82, 83, 87) supports the notion that networking can be developed at school and mentions that classmates from high school, university, college or other educational training organisations can be included in networking efforts.

\section{Networking during tertiary education}

Participants experienced that at university students are formally grouped together according to their fields of study or their sporting activities. The following quotations support this finding: "Some specific relationship networks come from your university days, from hostel days and an informal environment." and "It is something to see, how many of our guys from the university environment do business with other guys from university and because of that connection, and that is actually dangerous because you start to make a uniform type of thing and that has its own risks and so that is the most difficult challenge that I know of." The literature does not distinguish between school and university as different phases or levels of networking. However, both are simultaneously discussed by Gruszczynski (2005), who states that networks can be characterised by various combinations of individual friends from university and school, neighbours and other personal relationships.

\section{Networking at work}

Participants feel that they spend a large part of their day at work and colleagues, therefore, constitute an important part of their networks: "It is something that people do and you build up your business network daily. I started building when I started working and only now I get something off, but the whole spin-off that you get of who you know, that is networking." and "I think you have your network grow as you go through your business life." Paul and Kaltenbach (2004: 32), amongst others, support the finding that a network can be built at work through mutually beneficial and strong relationships within a business by means of professional and personal contacts.

\section{Networking at cultural and community events}

According to $70 \%$ of the participants, cultural and community events also group people with similar interests together and this commonality leads to a kinship and a sharing of information. Homogenous groups in terms of demography or shared interests seem to be a common occurrence when networks are developed. The following supports this: "I attend cultural events; I have learned that if you know people in non work-related projects in the community, then you build trust so much faster, but you also see people there where they are exposed and vulnerable, you see someone faster than in a company. So I have found that community projects are a fantastic way to create jobs in networking." Lindenfield and Lindenfield (2005: 233) support the idea of alumni organisations, sport or health clubs, parent associations, interest groups, local community projects and volunteer work as possible loci for 
networking. Others authors that mention homogenous gathering as a tendency in network development include amongst others Brass (1985) and Ibarra (1992) that found that men and women seem to gather in separate groups based on the tendency to groups with similar others. Mehra, Kilduff and Brass (1998) focused on the tendency of minority racial groups to form a network. Networks can also be based on relational and organisational demography as was found by Tsui and O’Reilly (1989) and Wagner, Pfeffer and O’Reilly (1984).

\section{Networking at networking events}

Participants expressed a clear difference of opinion regarding networking events and the effectiveness thereof for actual networking with a purpose. Five of the participants did not positively perceive of networking events to the same extent as described in the literature. The following quotation provides supportive evidence: "Then you have the Round Table type of thing. Together because of charity and then you have a different purpose? I think networking events could have different purposes." In the literature, networking groups are also referred to as affinity groups, in which similar interests and assets of value are grouped to offer an environment in which information is shared, support is offered and strategic initiatives are provided (McGrath \& Sparks, 2005: 49; Sparks, 2004:44).

\section{Networking in chambers of commerce}

Participants expressed a difference of opinion regarding chambers of commerce in general as a locus to network. Three participants referred to their own negative experiences of chambers of commerce, stating that they feel that the objectives of the specific chamber of commerce concerned had not been achieved. The following remark supports this finding: "Two months back I decided to join the chamber of commerce, I experienced the chamber of commerce as a place only for insurance agents, estate agents and other people that want to suck something out of you, and I can only expose myself to so many mosquitoes at one time. So if they ask you to invite your friends you cannot do that to them." Other participants remarked that even though some may perceive the meetings of the chamber of commerce as not quite what they had expected, it could be a helpful offset point to meet the appropriate people in order to build a network. This, however, is only achieved through a personal sustainable effort. The following quotations support this finding: “We want to be part of something, a group of people with similar business interests, professionals with a similar set of skills" and "In other organisations, you test your network, you spend a lot of time to do it and it does not work. You measure the effectiveness of your network and this depends on whether it is part of your business, or part of your normal life; it is difficult to see its effectiveness." Although chambers of commerce and other professional organisations are included in most of the literature under investigation (Khemka, 2005; Singer, 2004, Wolk \& Pont, 2005; Bøllingtoft \& Ulhøi, 2005, Baumann, 2004), participants seem to have varied opinions on the value of these organisations for networking. This is a unique finding because all the literature consulted appears to encourage the use of chambers of commerce as loci of potential networking and an opportunity to meet individuals with a common purpose in terms of furthering their business and building successful relationships.

\section{Quantitative findings on networking practices}

The questionnaire findings produced more detail on specific individual or human characteristics of networking. Networking practices and the successful implementation of networking in businesses differ from business to business and can be adapted to suit specific needs. During the focus group discussions, it became apparent that although different businesses have different networking practices, the main thrust behind networking remains the same for any networking activity. The line of questioning was designed to prompt participants to evaluate their own networking practices. The responses to these questions are summarised in Table 3.

Table 3: Participants' networking practices

\begin{tabular}{l|c|c}
\hline Networking practice & $\begin{array}{c}\text { Yes } \\
\mathbf{\%}\end{array}$ & $\begin{array}{c}\text { No } \\
\mathbf{\%}\end{array}$ \\
\hline $\begin{array}{l}\text { You tend to focus on a few important relationships. } \\
\text { You are patient in interaction and focus on }\end{array}$ & & \\
achieving the task or goal ahead. & 57 & 43 \\
You balance new and old relationships in an active & & \\
and comfortable way. You adapt to develop & & \\
networks and easily widen your range. & 83 & 17 \\
You know many connections, but do not organise & & \\
or follow them up. & 34 & 66 \\
You are a quiet and introverted person that follows & & \\
a step-by-step process in networking. & 17 & 83 \\
You make contact over the telephone. & 26 & 74 \\
You only make contact by e-mail. & 51 & 97 \\
You make contact via telephone and e-mail. & 83 & 17 \\
You make face-to-face contact. & \\
\hline
\end{tabular}

A large number of participants (57\%) tend to focus on a few important relationships because of time pressures related to their positions in the business. A small percentage of participants (17\%) appear to follow a stepby-step networking process and are unable to network naturally.

A significant finding that supports the findings in the literature study and the focus group discussions is that the majority of the participants (83\%) tend to build the strongest and most important relationships by making faceto-face contact. After the initial personal contact the participants indicated that they use technologies, such as email and the telephone to maintain contact. Only 51\% of participants indicated that they use the telephone and e-mail to establish an initial connection point if a first meeting or physical presence is not possible. 


\section{Sphere of influence}

The findings of the qualitative research with regard to the participants' spheres of influence on different groups of people were tested in the questionnaire. This question prompted participants to indicate all the different groups of people who are included in their spheres of influence. Table 4 summarises the findings.

\section{Table 4: Participants'sphere of influence}

\begin{tabular}{l|c|c}
\hline Groups of people & Yes \% & No \% \\
\hline Family & 89 & 11 \\
\hline Friends & 86 & 14 \\
\hline Neighbours & 26 & 74 \\
\hline Business acquaintances & 94 & 6 \\
\hline Suppliers & 49 & 51 \\
\hline Customers & 86 & 14 \\
\hline
\end{tabular}

Most of the participants believe that they have a sphere of influence on business acquaintances (94\%), family (89\%) and friends (86\%). A surprising finding, however, is that $86 \%$ of participants also believe that they have a sphere of influence on their customers. These findings were not specifically highlighted in the qualitative research. However, focus group participants were asked to list who they would include in their networking efforts and they responded by listing family, friends, social acquaintances and business contacts.

\section{Networking has a multiplier effect}

From the literature and the qualitative analysis, it became evident that individuals tend to gain easier access to further connections and relationships through the existing relationships and connections in their networks. Table 5 illustrates the evaluation of existing connections in terms of the potential connections accessible through them.

Table 5: Connections made possible through existing connections

\begin{tabular}{l|c|c}
\hline Existing connections & Yes \% & No \% \\
\hline Banks & 71,43 & 28,57 \\
\hline Government & 54,29 & 45,71 \\
\hline Chambers of Commerce & 51,43 & 48,57 \\
\hline Foreign investors & 40,00 & 60,00 \\
\hline Foreign partners & 60,00 & 40,00 \\
\hline Competitors & 48,57 & 51,43 \\
\hline Producers & 62,86 & 37,14 \\
\hline Customers & 94,29 & 5,71 \\
\hline
\end{tabular}

The following connections proved to be popular in this regard: customers (94.29\%), connections with banks (71.43\%), links or connections to producers (62.86\%) and foreign partnership relationships (60\%).
In this section, the analysis was aimed at the entire participating population. The aim was to determine the loci in which the participants practice networking. The extent to which the ideal situation differs from the current situation was calculated by subtracting the ideal count from the current count for each participant. Effect sizes are normally calculated in situations in which the entire population is included. The Gauteng business community is however a vast and not easily accessible population; thus, for the purpose of this study the included purposive sample can be viewed as a sub-population of the Gauteng business population and no generalisations relating to the entire South African population or other demographic areas in South Africa can be made.

For reporting purposes, the guidelines for effect sizes as developed by Cohen (1988:222-223) were used to calculate the effect sizes, in order to determine the significance of differences between the current and ideal findings (Ellis \& Steyn, 2003:52):

$\mathrm{d}=\frac{\left|\overline{\mathrm{x}}_{1}-\overline{\mathrm{x}}_{2}\right|}{\mathrm{S}}$

where

$d=0.2$ indicates a small effect; $d=0.5$ indicates a medium effect; and $d \geq 0.8$ indicates a large effect that is of practical significance (Cohen, 1988: 222-223).

\section{Loci to investigate for possible network building}

The participants indicated that they currently network in various loci and this differs in some instances from where they would ideally like to network. Table 6 provides a summary of the ideal and current loci to network according to the participants' circumstances.

Participants indicated that currently their businesses largely make use of trade organisations of their best customers and national trade shows, conventions and seminars to network. They indicated that they feel that these loci could be utilised to a greater extent in ideal circumstances. This finding indicates a large practical significance as to the relation amongst these loci as actual venues to investigate for network building. Traditional business venues are included as loci for networking, with national trade shows and conferences $(d=1.03)$ and trade organisations $(d=0.8)$; however, a surprising number of traditional 'social' venues are also seen as important in networking efforts, with volunteer work $(d=0.69)$, cultural events $(d=0.68)$ and even membership of organisations, such as Kiwanis and involvement in community projects $(d=0.64)$ viewed as currently important for network building, but particularly ideally important for future endeavours. 
Table 6: Current and ideal loci for network

\begin{tabular}{|c|c|c|c|c|c|}
\hline Loci & $\begin{array}{c}\text { Average } \\
\text { Currently }\end{array}$ & $\begin{array}{c}\text { Dev. of } \\
\text { Currently }^{\circ}\end{array}$ & Ideally & $\begin{array}{l}\text { Std. dev. } \\
\text { Ideally }^{\circ}\end{array}$ & $\begin{array}{c}\text { Effect size } \\
\text { (d-value) }\end{array}$ \\
\hline $\begin{array}{l}\text { National trade shows, } \\
\text { conventions/conferences }\end{array}$ & 2,58 & 1,00 & 2,13 & 0,92 & $1,03 \triangle$ \\
\hline $\begin{array}{l}\text { Trade organisations of your best } \\
\text { customers }\end{array}$ & 2,67 & 1,02 & 2,12 & 0,82 & $0,8 \triangle$ \\
\hline Professional and trade organisations & 2,21 & 1,09 & 1,93 & 0,93 & $0,69 *$ \\
\hline Volunteer work & 3,42 & 0,72 & 2,88 & 1,04 & $0,69 *$ \\
\hline Cultural events & 3,42 & 0,72 & 3,03 & 0,93 & $0,68 *$ \\
\hline Kiwani’s. Rotary. etc. & 3,53 & 0,68 & 3,06 & 1,01 & $0,64 *$ \\
\hline Community projects & 3,16 & 0,95 & 2,77 & 1,09 & $0,64 *$ \\
\hline Workshops, classes and seminars & 2,50 & 1,02 & 2,09 & 0,98 & $0,62 *$ \\
\hline Leads groups & 2,79 & 0,88 & 2,43 & 1,07 & $0,62 *$ \\
\hline Small business development centres & 3,03 & 0,97 & 2,53 & 1,02 & $0,59 *$ \\
\hline
\end{tabular}

${ }^{\circ}$ Standard deviation; * Medium effect size; and $\triangle$ Large practical significance

\section{Conclusions}

There appears to be consensus on the importance of networking, whether it is in an individual's personal or business life. Some believe that it should not be seen as mutually exclusive, but rather mutually inclusive. Networking takes place in a variety of settings with most activity currently in traditional business venues, but there is a significant shift to the inclusion of traditional social venues as ideal loci for networking.

Even though networking is considered important it has not received emphasis in training as an essential skill up to now. An individual needs to be of value: assisting or contributing to the success of others, and building bridges for one another will enhance an individual's interconnectedness and help to guide the individual towards new solutions and commitment. Business training courses do not accord networking the status it deserves as part of the necessary management toolbox and as part of essential business skills. In certain business contexts, it is not considered a core element for business success but an optional extra (a luxury). This notion is challenged by the current study, which has demonstrated that $97 \%$ of the participants use networking to bring in new business or to access additional business opportunities.

\section{Recommendations}

Networking should be approached within the context in which it takes place and an individual's own approach should be adapted accordingly. In order to develop a distinctive style of networking, an individual needs to begin developing his or her own way of networking early on. Network development should form part of a life skills programme in the school syllabus in order to develop these essential skills at an early age.

Network development should also be included in management training courses and on-the-job training in order to assist employees in understanding and developing their not only own networks, but also other people's approach to networking. In such training, people should be taught the principles of networking and the application thereof in practical networking situations.

The design of networking training courses at different levels and stages of an individual's career, in other words for career advancement and business success, should be accorded attention. Through such courses, an individual can better equip himself or herself for networking success. It is never too late to benefit from and to acknowledge networking as a skill and to learn to practice it.

For the purposes of this study, a non-probability sampling method was used and therefore the results are not representative of the entire population and only represent the views of those respondents investigated. Future research could be expanded to include other regions of South Africa.

\section{References}

Baumann, C.S. 2004. 'Business chamber's networking arm gaining muscle’, Orlando Business Journal, 21(4):8.

Boe, A. 1994. Networking success: How to turn business and financial relationships into fun and profit. Sacramento, CA: Health Communications.

Brass, D.J. 1985. 'Men’s and women's networks: A study of interaction patterns and influence in an organisation', Academy of Management Journal, 28: 327-343.

Brass, D.J., Galaskiewicz, J., Greve, H.R. \& Tsai, W. 2004. 'Taking stock of networks and organizations: A multilevel perspective', Academy of Management Journal, 47(6): 795-817.

Bøllingtoft, A. \& Ulhøi, J.P. 2005. 'The networked business incubator - leveraging entrepreneurial agency?, Journal of Business Venturing, 20(2):265. 
Breakwell, G.M. (Ed.). 2004. Doing social psychology research. Oxford: Blackwell.

Butler, J.E. (Ed.). 2004. Opportunity identification and entrepreneurial behavior. Hartford, CT: Information Age Publishing.

Cohen, J. 1988. Statistical power analysis for behavioural sciences. $2^{\text {nd }}$ Edition. Hillsdale, NJ: Erlbaum.

Cooper, D.R. \& Schindler, P.S. 2003. Business research methods. $8^{\text {th }}$ Edition. New York: McGraw-Hill.

Creswell, J.W. 1994. Research design: qualitative and quantitative approaches. Sacramento, CA: Sage.

Daymon, C. \& Holloway, I. 2002. Qualitative research methods in public relations and marketing communications. London: Routledge.

De Klerk, S. \& Kroon, J. 2008. 'Business networking relationships for business success', South African Journal of Business Management, 39(2): 25-35.

De Man, A. 2004. The Networked Economy: Strategy, structure and management. Cheltenham, UK : Edgar Elgar.

De Vos, A.S. 2005. 'Combined quantitative and qualitative approach'. In: De Vos, A.S., Strydom, H., Fouche, C.B. \& Delport, C.S.L. (Eds.). Research at grass roots for the social sciences and human service professions. $3^{\text {rd }}$ Edition. Pretoria: Van Schaik.

Ellis, S.M. \& Steyn, H.S. 2003. 'Practical significance (effect sizes) versus or in combination with statistical significance ( $p$-values)', Management Dynamics, 12(4): 51-53.

Fischer, A. 2005. 'How to network - and enjoy it', Fortune, 151(7): 38.

Frazier, B.J. \& Niehm, L.S. 2004. 'Exploring business information networks of small retailers in rural communities', Journal of Developmental Entrepreneurship, 9(1): 23-40.

Greeff, M. 2006. 'Verbal communication with the consultant'. Potchefstroom. (Original notes in possession of the author.)

Gruszczynski, W. 2005. 'Small enterprises’ cooperation groups: Importance of personal relationships in small enterprises' cooperation'. Unpublished paper delivered at the 4th International Conference of Entrepreneurship: Employment and beyond, September 8-9, 2005. Sodertörns Högskola University College, Stockholm, Sweden.

Guba, E.G. 1981. 'Criteria for assessing the trustworthiness of naturalistic inquiries', Educational
Resources Information Centre Annual Review Paper, 29: 75-91.

Holloway, I. \& Wheeler, S. 2002. Qualitative research in nursing. $2^{\text {nd }}$ Edition. Oxford: Blackwell.

Ibarra, H. 1992. 'Homophily and differential returns: Sex differences in network structure and access in an advertising firm', Administrative Science Quarterly, 37: 422-447.

Impact Factory. 2006. 'Business networking course'. [online:] URL: http://www.impactfactory.com/cgibin/search/search.pl?Terms=business+networking+skills\&s ubmit.x=15\&submit.y=5 . Accessed 19 August 2009.

Igwebuike, J.G. 1998. 'Networking strategies and degree of job satisfaction of Greater Columbus, Ohio managers', Proquest Dissertations and Theses. Columbus, OH: The Ohio State University (Dissertation).

Kadushin, C. 2002. 'The motivational foundation of social networks', Social Networks, 24: 77-91.

Kay, F. 2004. Brilliant business connections: How powerful networking can transform you and your company's performance. Oxford: How to Books.

Khemka, S. 2005. 'Effective networking', Hospital Doctor, 4(May):12.

Koniordos, S.M. (Ed.). 2005. Networks, trust and social capital: Theoretical and empirical investigations from Europe. Hants: Ashgate Publishing.

Krefting, L. 1991. 'Rigor in qualitative research: The assessment of trustworthiness', The American Journal of Occupational Therapy, 45(3): 214-222.

Kruger, D.J., De Vos, A.S., Fouché, C.B. \& Venter, L. 2005. 'Quantitative data analysis and interpretation'. In: De Vos, A.S., Strydom, H., Fouche, C.B. \& Delport, C.S.L. (Eds.). Research at grass roots for the social sciences and human service professions. $3^{\text {rd }}$ Edition. Pretoria: Van Schaik.

Lewis, J.P. 2003. Project leadership. New York: McGraw-Hill.

Lincoln, Y.S. \& Guba, E.A. 1985. Naturalistic inquiry. London: Sage.

Lindenfield, G. \& Lindenfield, S. 2005. Confident networking for career success and satisfaction. London: Piatkus.

Lindsay, D. 2005. Cracking the networking CODE. $2^{\text {nd }}$ Edition. Plano, TX : World Gumbo Publishing. 
Marschan-Piekkari, R. \& Welch, C. (Eds.). 2004. Handbook of qualitative research methods for international business. Cheltenham: Edgar-Elgar.

McGrath, R. Jr \& Sparks, W.L. 2005. 'The importance of building social capital', Quality Process, 38(2): 45-50.

Mehra, A., Kilduff, M. \& Brass, D.J. 1998. 'At the margins: A distinctiveness approach to the social identity and social networks of underrepresented groups', Academy of Management Journal, 41: 441-452.

Miller, L. 2003. 'Personalities at work: understanding and managing human nature on the job', Public Personnel Management, 32(3): 419-434.

Möller, K., Rajala, A. \& Svahn, S. 2005. 'Strategic business nets: Their type and management', Journal of Business Research, 58(9):1274-1284.

Mooradian, T.A. \& Swan, K.S. 2006. 'Personality-andculture: the case of national extraversion and word-ofmouth', Journal of Business Research, 59(6):778-785.

Neal, J.W. 2009. 'Network ties and mean lies: A relational approach to relational aggression', Journal of Community Psychology, 37(6): 737-753.

Nierenberg, A.R. 2005a. Million dollar networking: The sure way to find, grow and keep your business. Herndon, VI: Capital Books.

Nierenberg, A.R. 2005b. 'Making new contacts', The American Salesman, 50(4): 3-8.

Paul, K. \& Kaltenbach, P. 2004. 'Networking beyond the business cards', Catalyst (Dublin, Ohio), 32(Sep.-Oct.) [online:] URL:

http://findarticles.com/p/articles/mi_hb042/is_2004_SeptOct/ai_n29152268

Pearse, N.J. \& Smith, C.O. 2005. 'Theory generation: An illustration of the use of grounded theory in management research', Management Dynamics, 14(2): 47-59.

QSR International. 2002a. NVivo 2.0. Doncaster: QSR International.

QSR International. 2002b. NVivo: Getting started in Nvivo. Doncaster: QSR International.

Richards, L. 2002. Introducing NVivo: A workshop handbook. Revised edition. Doncaster: Qualitative Solutions and Research.

Rothmann, S. \& Van der Bank, M. 2006. 'Correlates of expatriates' cross-cultural adjustment', Management Dynamics, 15(4): 29-39.

SAS Institute Inc. 2005a. SAS OnlineDoc, Version 9.1. Cary, NC: SAS.
SAS Institute Inc. 2005b. The SAS System for Windows, Release 9.1 TS Level 1M0. Cary, NC: SAS.

Singer, B. 2004. The ABC's of building a business team that wins: The invisible code of honor that takes ordinary people and turns them into a championship team. New York : Warner Business Books.

South Africa Info: The official gateway. 2009. 'Employment equity reports due soon'. SAPA, 8 September 2009. [online]

URL:http://www.southafrica.info/pls/procs/iac.page?p_tl=6 96\&p_t2=7396\&p_t3=0\&p_t4=0\&p_dynamic . Accessed 14 September 2009.

Sparks, G. 2004. 'Networking with a purpose: Women-towomen associations help build business', St. Louis Commerce Magazine, Jul:44.

Takash, J. 2004. 'Networking success: Discover the tools you need to get to the top', Business Credit, 106(4): 24-25.

Taylor, J. 2006. Monster careers: Networking. New York: Penguin.

Thompson, L. 1996. 'School ties: A social network analysis of friendships in a multilingual kindergarten', European Early Childhood Research Journal, 4(1): 49-69.

Tullier, L.M. 2004. Networking for job search and career success. $2^{\text {nd }}$ Edition. Indianapolis, IN: JIST Works.

Tsui, A.E. \& O’Reilly, C.A. 1989. 'Beyond simple demographic effects: The importance of relational demography in superior-subordinate dyads', Academy of Management Journal, 32: 402-423.

Van Winkelen, C. 2003. 'Inter-organisational communities of practice’. [online] URL:

http://www.elearningeuropa.info/directory/index.php?page =doc\&doc_id=1483\&doclng=6.

Wagner, G.W., Pfeffer, J. \& O’Reilly, C.A. III. 1984. 'Organizational demography and turnover in top management groups', Administrative Science Quarterly, 29: 74-92.

Wainwright, C.M. 2004. 'Mentoring and networking', Mercer Business, 80(12): 28.

Ward, P.L. 2000. 'An overview of the literature of management and of information and library services management 1999', Library Management, 21(3): 128-152.

Webster's third new international dictionary of the English language : Unabridged . 1976. Editor in chief, Philip Babcock Gove and the Merriam-Webster editorial staff. Springfield, Mass: Merriam. 
White, H. 2004. Networking for business success: Quick tips for busy people. London: WritersPrintShop.

Wolk, D. \& Pont, J. 2005. 'At social job sites, it's who you know’, Workforce Management, 84(5):52.

Yeung, R. 2006. The rules of networking. London: Cyan Communications.

Zweibel, B. 2006. 'How to improve your networking skills'. [online]

URL:http://www.questcareer.com/networking_skills.htm.

Accessed 18 Aug. 2009. 